\title{
Seasonal patterns of sedimentary carbon and anaerobic respiration along a simulated eutrophication gradient
}

\author{
P. Sampou*, C. A. Oviatt \\ University of Rhode Island, Graduate School of Oceanography, Kingston, Rhode Island 02881, USA
}

\begin{abstract}
Concentrations of organic carbon and rates of dissimilative sulfate reduction in surface sediments of marine mesocosms were examined along an experimental eutrophication gradient. Phytoplankton biomass increased due to addition of inorganic nutrients (N, P. Si). This increase was especially pronounced during the winter-spring diatom blooms, which increased in magnitude and duration along the nutrient gradient. Net system production in winter and spring resulted in carbon deposition and accumulation in surface sediments (maximum net accumulation $17 \mathrm{~mol} \mathrm{C} \mathrm{m}^{-2}$ ). Benthic remineralization of carbon excceded depositional supply during summer and fall. Sediment carbon concentrations approached background levels in December and February, suggesting very little annual accumulation of sediment carbon. Sediment oxygen consumption and sulfate reduction rates both increased as a result of carbon sedimentation. Sulfate reduction rates in organic enriched sedıments were an order of magnitude higher than control and were correlated with temperature and carbon concentrations $\left(r^{2}=0.85\right)$. Anaerobic respiration rates in unenriched sediments were related only to seasonal patterns of temperature $\left(r^{2}=0.70\right)$. Anaerobic metabolism was the dominant metabolic pathway in control and treated sediments, with 50 to $70 \%$ of annual carbon remineralization due to sulfate reduction.
\end{abstract}

\section{INTRODUCTION}

Seasonal patterns of water-column primary production and biomass for temperate coastal waters have been well studied and generally follow a succession of changes. A winter-spring diatom increase in both production and biomass is followed by a late spring/early summer period of rapid biomass decline due to grazing and nutrient limitation. A series of rapid blooms with high production and lower overall biomass occurs during the summer. A fall transition period may exhibit a secondary peak in biomass and production. Finally, a period of very low production and biomass occurs in late fall and early winter (Pratt 1965. Smayda 1973. Boynton et al. 1982, Smetacek et al. 1984, Malone et al. 1988). There is evidence that such a pattern of watercolumn plankton dynamics results in seasonal differences in input and temporary storage of organic detritus to the sediments in plankton-dominated coast-

\footnotetext{
- Current address: University of Maryland, PO Box 775, Cam-
} bridge, Maryland 21613, USA al marine ecosystems (Rudnick 1984, Riebesell 1989, Alldredge \& Gotschalk 1989). Smetacek (1984) has argued that Kiel Bight sediments receive the majority of organic sedimentation (over an annual cycle) during the winter-spring phytoplankton bloom. A large portion $(>50 \%)$ of primary production produced during that time was deposited to the benthos (Peinert et al. 1982, Graf et al. 1984). Rudnick \& Oviatt (1986) found that a substantial fraction of radiolabeled organic matter deposited through the winter remained in the sediments at the beginning of July.

Eutrophication in coastal marine systems may significantly increase organic sedimentation and seasonal storage of organic matter in surface sediments. Nutrient additions increased the duration and magnitude of winter-spring diatom blooms (Oviatt et al. 1986). Seasonal patterns of net system autotrophy and heterotrophy also implied a net accumulation of organic matter through the winter and spring, with a remineralization of carbon during the summer and fall (Oviatt et al. 1986).

Sedimentation of organic matter stimulates benthic 
metabolism (Graf et al. 1982, Kelly \& Nixon 1984, Jensen et al. 1990). However, seasonal inputs of carbon may be out of phase with other processes controlling sediment respiration rates (e.g. temperature, cycles in faunal populations). These controlling factors can confuse a simple prediction of the benthic response to deposited detritus.

Organic-matter remineralization in nearshore marine sediments is dominated by anaerobic metabolism, specifically by sulfate reduction and the assaciated fermentative bacterial community (Jørgensen 1977. Sørensen et a1. 1979, Martens \& Klump 1984). Jørgensen (1982) combined the observations that sulfate reduction rates correlated with sedimentation rates (Berner 1978) and that total benthic metabolism increased due to organic sedimentation (Toth \& Ler$\operatorname{man} 1977$ ) and proposed that the relative fraction of sulfate reduction versus total sediment respiration increases with rising benthic metabolism.

The present study examined the effects of nutrient enrichment on transport of carbon to the sediment surface and its subsequent remineralization in coastal marine mesocosms. The questions examined were: (1) Did nutrient enrichment increase carbon sedimentation? (2) Did increased carbon deposition affect sediment metabolism and the relative importance of anaerobic respiration via sulfate reduction? (3) How did the seasonality of these 2 processes, organic sedimentation and its subsequent decomposition in the sediments, influence carbon cycling in coastal marine sediments?

\section{METHODS}

Experimental facility. This work was conducted at the Marine Ecosystem Research Laboratory (MERL) in Narragansett, Rhode Island, USA, as part of a 28 mo experiment examining effects of nutrient enrichment on nearshore marine ecosystems (June 1981 through September 1983). The mesocosms were large cylindrical tanks (1.83 m diameter, $5.49 \mathrm{~m}$ height) filled with $13 \mathrm{~m}^{3}$ seawater overlying a functioning benthic community $\left(2.5 \mathrm{~m}^{2}\right.$ area, $37 \mathrm{~cm}$ depth). Collection and transfer of the benthos from Narragansett Bay was accomplished with a minimum of biological and chemical disturbance (Hunt \& Smith 1983). The mesocosms were physically scaled to Narragansett Bay in terms of sunlight, temperature (ambient bay temperature \pm $\left.2{ }^{\circ} \mathrm{C}\right)$, flushing $\left(3.7 \%\right.$ volume exchange $\left.\mathrm{d}^{-1}\right)$ and tidal mixing (rotating plungers mix the water column 2 h on and 4 h off, resuspending bottom sediments to roughly $3 \mathrm{mg} \mathrm{l}^{-1}$ ) (Pilson et al. 1979. Nixon et al. 1980, Oviatt et al. 1982). Water-column light extinction usually allowed $<1 \%$ of surface irradiance to reach the bottom, thus maintaining the sediments in a heterotrophic condition. Fouling on the mesocosm sides was minimized by biweekly brushing in summer and once a week during the rest of the year.

Experiment. Nine mesocosms were involved in the eutrophication experiment. Three control tanks had no nutrient additions, and 6 tanks received $\mathrm{N}, \mathrm{P}$, and $\mathrm{Si}$ as inorganic salts $\left(\mathrm{NH}_{4} \mathrm{Cl}, \mathrm{KH}_{2} \mathrm{PO}_{4}, \mathrm{Na}_{2} \mathrm{SiO}_{3} \cdot 9 \mathrm{H}_{2} \mathrm{O}\right)$ at molar ratios characteristic of sewage effluent entering Narragansett Bay (12.8:1.0:0.91, respectively) (Nixon 1981). The nutrients were added daily to mesocosms in a geometric loading progression $(1 \times, 2 \times, 4 \times, 8 \times, 16 \times$, $32 \times)$. The least-loaded treatment $(1 \times)$ received $2.88 \mathrm{mM} \mathrm{N} \mathrm{m} \mathrm{m}^{-2} \mathrm{~d}^{-1}$, the average Narragansett Bay wide areal $N$ loading (Nixon 1981). The highest treatment $(32 \times)$ had 32 times more nutrients added (92.1 $\mathrm{mMN}, 7.2 \mathrm{mM}$ P, $6.6 \mathrm{mM} \mathrm{Si}$ ) each day. An overview of the eutrophication experiment was provided by Nixon et al. (1984). Additional results were presented by Oviatt et al. (1986) and Kelly et al. (1985). The data discussed in the present paper were collected during the last 17 mo of the experiment (April 1982 through September 1983) from 5 of the 9 mesocosms (a control, $4 \times, 8 \times, 16 \times, 32 \times)$.

Analytical methods. Weekly phytoplankton biomass was sampled during the morning mixing cycle. Chlorophyll a was analyzed using methods outlined by Yentsch \& Menzel (1963), modified by Lorenzen (1966) and adapted for use in these experiments (Lambert \& Oviatt 1986). Replicate $10 \mathrm{ml}$ aliquots were pipetted from well-mixed sample bottles and filtered onto Whatman-type GF/F glass fiber filters. The filters were folded into quarters, placed into an aluminum-foil packet and stored frozen over desiccant $(<1 \mathrm{mo})$ until analysis. Chl a was extracted by grinding in $90 \%$ acetone and quantified on a Turner Model III fluorometer. Precision was $2.7 \%$ coefficient of variation (Lambert \& Oviatt 1986).

Benthic oxygen uptake was measured 9 times between June 1982 and September 1983. The entire sediment surface was covered with a benthic flux chamber (described by Oviatt et al. 1982, 1984). Initial and final water samples were siphoned from the chamber following 2 to 5 min of gentle stirring. Incubation times were limited to yield a final oxygen concentration of ca $75 \%$ of initial value.

Dissolved oxygen consumption within the benthic chamber was corrected for water-column oxygen uptake to yield sediment oxygen consumption (SOC). Water-column oxygen consumption was calculated from changes in dissolved oxygen in a glass biological oxygen demand (BOD) bottle $(300 \mathrm{ml})$ filled with initial chamber water and lowered to rest on top of the chamber Oxygen determinations followed a modified Winkler technique (Lambert \& Oviatt 1986). Replication of SOC was good among the 3 control mesocosms, 
with the coefficient of variation normally less than $10 \%$ (Frithsen et al. 1985). Annual integrated SOC was calculated from individual measurements by trapezoidal integration over time and summed for 1 yr (22 September 1982 to 21 September 1983).

Sediment cores for sulfate reduction measurements and sediment characterization were taken in acrylic tubes using pole-mounted flow-through corers [Frithsen et al. (1983) for a $2.5 \mathrm{~cm}$ diameter corer and a 'Benthos' (Woods Hole, Massachusetts, USA) corer for the $6.7 \mathrm{~cm}$ diameter]. Intact sampling of surface flocculent layers was achieved. The water-capped cores were immediately transferred to a temperature-controlled room (set to ambient tank temperature) for processing.

Downcore profiles of redox potential (Eh), pH, porewater sulfate, porosity and solid-phase carbon and nitrogen ( $\mathrm{C}$ and $\mathrm{N}$ ) measurements were made on the $6.7 \mathrm{~cm}$ diameter cores. Eh was measured with a Methrohm combination 'Eh' platinum electrode, corrected for silver/silver chloride reference electrode potential at the temperature of measurement (Sawyer \& Roberts 1974). The electrode was cleaned and then standardized in a quinhydrone $\mathrm{pH} 7$ buffer solution prior to each series of measurements. The $\mathrm{pH}$ profiles of interstitial waters were done concurrently with Eh using a Thomas combination $\mathrm{pH}$ electrode calibrated at ambient tank temperatures with $\mathrm{pH} 4$ and $\mathrm{pH} 7$ buffers. Both probes were allowed to equilibrate in seawater overlying the sediments prior to sediment profiling. Measurements were recorded at $1 \mathrm{~cm}$ intervals beginning at $0.5 \mathrm{~cm}$. Readings were allowed to stabilize at each depth (15 min).

Following the Eh/pH profiles, the sediment was extruded from the core tube and sliced into $1 \mathrm{~cm}$ sections. The slices were transferred to $150 \mathrm{ml}$ polyethylene centrifuge bottles. A mixed subsample $(5 \mathrm{~g})$ was placed in a tared aluminum weighing dish and saved for porosity and $\mathrm{C}$ and $\mathrm{N}$ analyses. Centrifuge bottles were purged with nitrogen gas during handling and capped. Centrifugation was done at ambient tank temperatures. The porewater was decanted into cleaned $25 \mathrm{ml}$ syringes fitted with $25 \mathrm{~mm}$ filter holders and $0.45 \mu \mathrm{m}$ Nuclepore filters. If free sulfide was present (detected by smell), the filtered porewater was purged with nitrogen gas.

Porewater was analyzed for sulfate using a reverse titrametric procedure (Howarth 1978). The procedure was standardized against a secondary seawater standard. Salinity of the secondary standard was calculated by a silver-chloride titration standardized against Copenhagen seawater. The coefficient of variation for sulfate analysis was $10 \%$.

Porosity, the percentage of space in the sediments occupied by seawater, was calculated from the difference between wet and dry weight and from the density of dry sediment. Wet weights were recorded within 10 min of subsampling. The sediments were dried at 60 to $80^{\circ} \mathrm{C}$ until constant weight was achieved. Dry sediment density was 2.30 and $2.55 \mathrm{~g} \mathrm{~cm}^{-3}$ for sediments heavily enriched with organic matter and for control sediments, respectively.

Sedimentary carbon and nitrogen analyses were done with a Carlo Erba model 1105 CHN elemental analyzer on dried, ground samples. Shell fragments were picked out of the sediments at all stages of processing, especially prior to grinding. Inorganic carbon constituted 5 to $10 \%$ of total carbon in control sediments picked clean of shell fragments (Sampou unpubl. data). Replicate $\mathrm{C}$ and $\mathrm{N}$ analyses were run for all samples. An acetanilide $(71.1 \% C, 10.4 \% \mathrm{~N})$ standard curve was run at the beginning and end of every day of analysis. Average relative error (range/mean) was $4 \%$ for the 200 samples tested.

A change in percentage carbon in surface sediments implied a net accumulation or remineralization of organic matter which could be expressed on a mass-perarea basis. Expressing carbon in these units would then enable direct comparisons with other system storage and rate measurements (i.e. primary production, phytoplankton biomass, benthic respiration, etc.). Percentage carbon was converted to $\mathrm{g} \mathrm{C} \mathrm{cm}^{-3}$ using porosity and dry-sediment density. Mass of $\mathrm{C} \mathrm{m}^{-2}$ can then be calculated from changes in carbon concentration in surface sediments summed to a chosen depth. However, a difficulty arose when using a depth reference in centimeters for sediment systems with large changes in seasonal and treatment porosity. A change in porosity from 0.75 to 0.95 would obscure an increase in carbon concentration from 2.1 to $5.2 \%$. There was 5 times more solid sediment at 0.75 porosity, so even though carbon concentration was only $40 \%$ of the carbon-rich sediment, the total number of grams of carbon in the surface $1 \mathrm{~cm}^{3}$ was greater. A downcore-integrated carbon measurement was normalized against a depth parameter independent of centimeters. Depth was normalized to $2.0 \mathrm{~g}$ carbon-free sediment $\left(\mathrm{S}_{\mathrm{cf}}\right)$ under $1 \mathrm{~cm}^{2}$ of the sediment surface. A mass of $2.0 \mathrm{~g}$ was chosen from the maximum depth $(\mathrm{cm})$ to which elevated carbon concentrations were detected ( $5 \mathrm{~cm} ; 32 \times$ treatment, July 1983). On this date and for all others the surface $2.0 \mathrm{~g}$ sediment under $1 \mathrm{~cm}^{2}$ included all detectable $C$ enrichment. The number of grams of carbon in association with this surface $2.0 \mathrm{~g} \mathrm{~S}_{\mathrm{ct}} \mathrm{cm}^{-2}$ was then calculated for each date and mesocosm, and compared, as follows:

$$
\mathrm{g} C \text { per } 2.0 \mathrm{~g} \mathrm{~S}_{\mathrm{Cf}} \mathrm{cm}^{-2}=\mathrm{g} C \text { per } \mathrm{S}_{\mathrm{cf}} \mathrm{cm}^{-3} \times Z_{\mathrm{cm}}
$$

where $Z_{c m}$ is the date- and tank-specific depth $(\mathrm{cm})$ to which $\mathrm{S}_{\mathrm{cl}} \mathrm{cm}^{-3}$ must be summed in order to reach $2.0 \mathrm{~g}$ $\mathrm{S}_{\mathrm{cf}} \mathrm{cm}^{-2}$. The results were converted to mol $\mathrm{C} \mathrm{m}^{-2}$ in the surface $20 \mathrm{~kg} \mathrm{~m}^{-2}$ of sediment. 
For these calculations several assumptions were necessary The first assumption was that each mesocosm began the experiment with similar sedimentary carbon profiles and that changes which did occur were the result of treatment effects (sediments were all collected from the same field site). Secondly, inorganic sedimentation could not differ among the mesocosms over the course of the experiment lall tanks received the same incoming feed seawater with its associated suspended load and had the overflow $(2.54 \mathrm{~cm}$ diameter) pipe $2.0 \mathrm{~m}$ off the bottom]. Thirdly, near-bottom bedload movement was prevented in the tanks so that changes in macrofaunal populations, which did occur and which could have altered flow characteristics at the sediment/water interface, did not significantly affect sedimentation rates. The final assumption was that carbon accumulation was restricted to surface sediments. Bioturbation would work surface deposition to depth, but there was no indication of deep burial based on $\mathrm{C}$ and $\mathrm{N}$ profiles.

Downcore sulfate reduction rates were measured over the last 15 mo of the experiment. Rate measurements were coordinated with benthic fluxes and sediment analyses. Six depths per core were inoculated with several microcuries of ${ }^{35} \mathrm{SO}_{4}$ (specific activity was roughly $\left.1 \mu \mathrm{Ci} \mathrm{I}^{-1}\right)$. Incubations of the whole core were run at ambient temperature for 4 to $24 \mathrm{~h}$ depending on temperature and bacterial activity. Extraction of labelled ${ }^{35} \mathrm{~S}$ pools began immediately after the incubation (Howarth \& Marino 1984). Sediment was extruded from the $2.5 \mathrm{~cm}$ cores, sliced (to contain the injection point in the middle of the slice), and transferred into a reaction jar. Phenethylamine-soaked paper wicks were suspended inside the oxygen-free reaction jar. Deoxygenated $\mathrm{H}_{2} \mathrm{SO}_{4}(50 \mathrm{ml} ; 1 \mathrm{~N})$ was added to the reaction vessel through a sealed septum. The sediment/acid slurry was stirred at room temperature for $2 \mathrm{~h}$, during which time acid-volatile sulfides (AVS) passively distilled out of solution and were trapped onto the phenethylamine wicks. The wicks and plastic wells holding them were placed in scintillation vials for radioactive counting. The sediment/acid slurry was then poured through a Whatman No. 54 glass-fiber filter $(5.5 \mathrm{~cm})$. Filtrate volume was recorded and a $1 \mathrm{ml}$ subsample was counted for radioactivity in the ${ }^{35} \mathrm{SO}_{4}$ pool. Since only a tiny fraction of the added ${ }^{35} \mathrm{SO}_{4}$ was reduced $(<1 \%)$ during incubation, the amount of radioactive sulfate added at the beginning of the experiment was assumed to be equivalent to the ${ }^{35} \mathrm{SO}_{4}$ recovered in the filtrate fraction. It was then necessary to thoroughly wash the sediment free of soluble ${ }^{35} \mathrm{SO}_{4}$, since just a small amount of contamination would lead to a large overestimation of ${ }^{35} \mathrm{~S}$-sulfides recovered in the aqua regia extraction. The filter and sediment were transferred to a glass beaker to which was added $5 \mathrm{ml}$
$+10 \mathrm{ml}$ of concentrated $\mathrm{HCl}$ and $\mathrm{HNO}_{3}$, respectively. The aqua regia digestion lasted for $24 \mathrm{~h}$, whereupon the digesting slurries were diluted and subsampled for radioactivity in this fraction.

Time-series incubations and replicate chromiumreduction extractions were run in this study to check the reliability of the aqua regia digestion for recovery of acid-insoluble sulfides in these sediments (Sampou 1989). Time-series incubations were linear over time but did yield a positive time-zero $t_{0}$ aqua regia blank of $0.052 \pm 0.040 \%(1 \mathrm{SD}, \mathrm{n}=11)$ of initially added ${ }^{35} \mathrm{SO}_{4}$. This recovery of radioactivity at $t_{0}$ does represent a limit on precision. The standard deviation of $t_{0}$ was equivalent to roughly $15 \mathrm{nmol} \mathrm{SO}_{4}$ reduced $\mathrm{cm}^{-1} \mathrm{~d}^{-1}$ for an average rate measurement $(10 \mu \mathrm{Ci}$ injected into a sediment horizon). A comparison between aqua regia and chromium-reduction digestion of acid-insoluble sulfides was run on replicate cores, yielding equivalent sulfate reduction rates (Sampou 1989). Chromium reduction is considered the least ambiguous extraction procedure and has become the extraction procedure of choice for measurement of sulfate reduction (Zhabina \& Volkov 1978, Howarth \& Jørgensen 1984, Canfield et al. 1986). Sulfate reduction rates were calculated using the equation of Jørgensen (1978) modified to include recovery of radiolabeled sulfide (corrected for $t_{0}$ blank) in the aqua regia extraction.

Replicated sulfate reduction measurements were run in February 1983 at minimum rates. Two to three depth replicates were run for each mesocosm. The average coefficient of variation was $30 \%$ in the replicate sets. Jørgensen (1977) ran several thousand replicated sulfate reduction measurements. He found that the standard deviation of the mean (based on $2.5 \mathrm{~cm}$ diameter whole-core incubations) was proportional to the rate of reduction and was on average $35 \%$.

Sulfate reduction and the equivalent carbon metabolic rate (2 carbons per sulfate), expressed per $\mathrm{cm}^{3}$, were integrated to a depth of $15 \mathrm{~cm}$ to yield a rate per area of sediment surface. Annual integrated rates were calculated from areal metabolism integrated (trapezoidal) over time.

\section{RESULTS}

\section{Phytoplankton biomass}

Phytoplankton biomass and net daytime production increased along the nutrient-addition gradient (Oviatt et al. 1986). The most pronounced effect of the nutrient additions was to increase the magnitude and duration of the winter-spring diatom bloom (Fig 1). Chl a concentrations of the winter-spring bloom were an order of magnitude higher in the treated tanks than in controls 


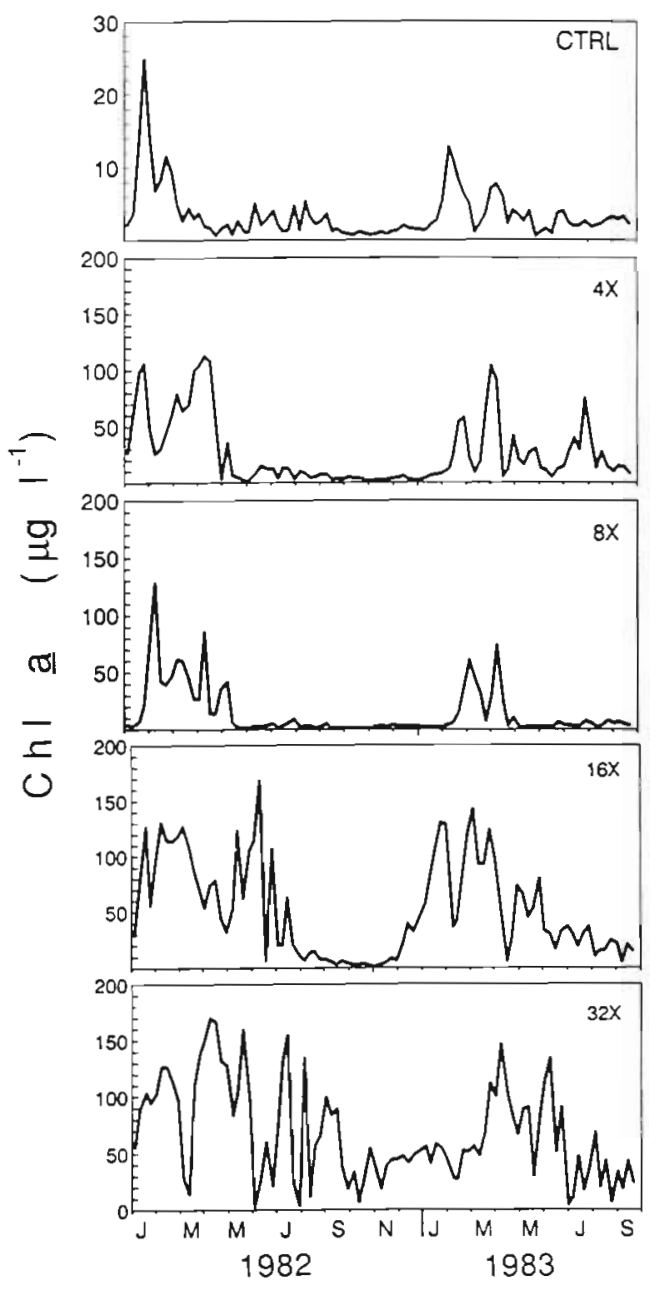

Fig. 1. Phytoplankton biomass as measured by chlorophyll a (chl a) concentration in control (CTRL) $4 \times, 8 \times, 16 \times$, and $32 \times$ treatments. Data collected weekly from January 1982 through September 1983. Note change in scale between CTRL and treatments (from Frithsen et al. 1985)

(excepting $8 \times$ ). The $32 \times$ treatment had chl a concentrations $>30 \mu \mathrm{g} \mathrm{l}^{-1}$ throughout much of the year.

\section{Sedimentary carbon concentrations}

High phytoplankton biomass, dominance by diatoms, and net autotrophy during the winter-spring season implied net deposition of organic carbon to the sediments. Percentage carbon in surface control sediments remained fairly constant for most of the year $(2.1$ $\pm 0.15 \%$ carbon), with a slight enrichment in June 1983 (Fig. 2). $4 \times$ sediments were indistinguishable from control sediments but the other 3 treatments $(8 \times$, $16 \times, 32 \times$ ) all showed a substantial spring build-up of carbon in surface sediments (Fig. 2). Concentrations increased from background levels in December 1982 and February 1983 to 2.6, 3.4 and 5.6\% in early and/or

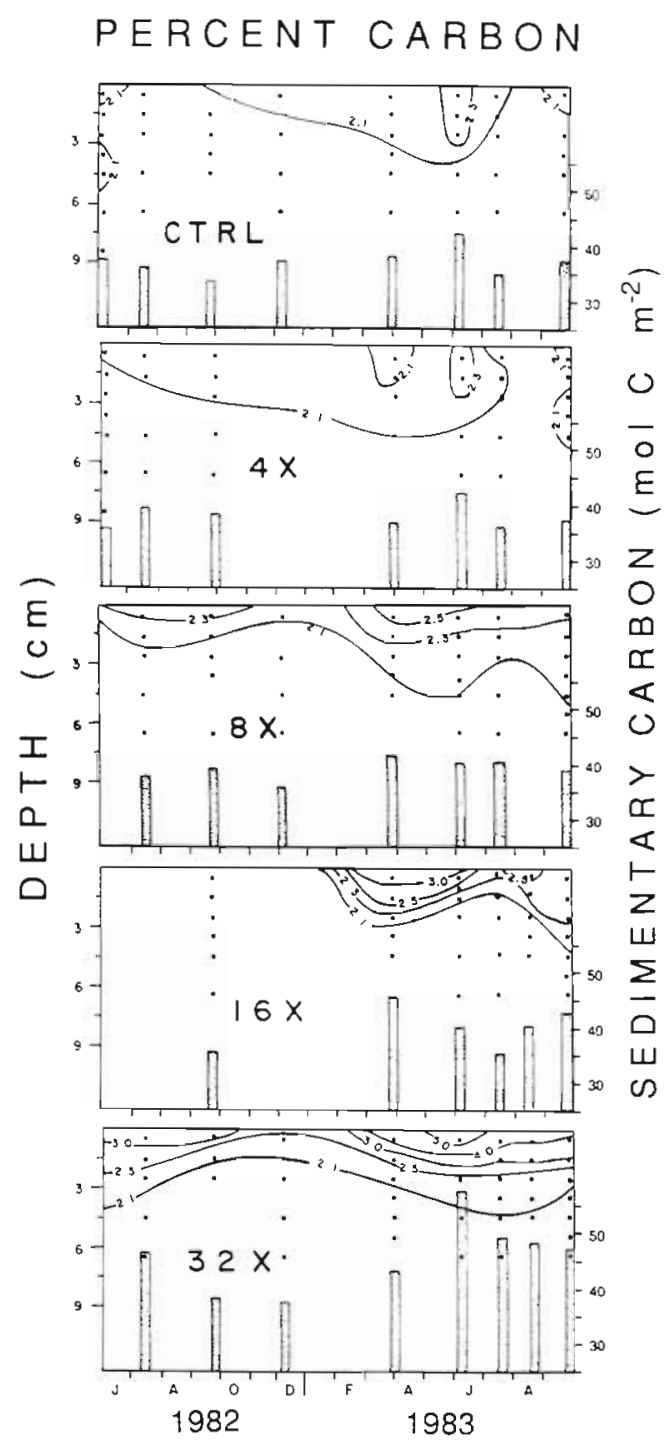

Fig. 2. Downcore sediment carbon concentrations for control (CTRL) $4 \times, 8 \times, 16 \times$ and $32 \times$ treatments (June 1982 to September 1983). Isopleths of percentage carbon from measured concentrations $(\bullet)$ at respective depths. Areal mass of carbon ( $\mathrm{mol} \mathrm{C} \mathrm{m} \mathrm{m}^{-2}$ ) calculated by integrating carbon profiles to a depth normalized to a dry sediment weight of $20 \mathrm{~kg} \mathrm{~m}^{-2}$ (see text for discussion)

late spring for $8 \times, 16 \times$ and $32 \times$ respectively. Declining carbon concentrations during summer and fall implied net remineralization of carbon in the surface sediments. Minimum carbon concentrations were recorded during fall $(1982,1983)$ and early winter $(1982)$. C:N ratios also indicated surface accumulation of fresh organic material through the spring, with $\mathrm{C}: \mathrm{N}$ ratios decreasing from surface control sediment ratios of 10-12 to as low as $7-8$ in enriched surface sediments. Carbon enrichment was restricted to surface sediments. Carbon concentrations were at background levels $(1.8$ to $2.0 \%)$ in all treatments at depths $>5 \mathrm{~cm}$. 


\section{Porosity}

Porosity did not change substantially from control sediments except for the $32 \times$ treatment. The surface $2 \mathrm{~cm}$ of $32 \times$ were more fluid throughout the year, particularly so in summer. Typical downcore porosity profiles for control and $32 \times$ are shown for both summer and winter conditions (Fig. 3). In this example there

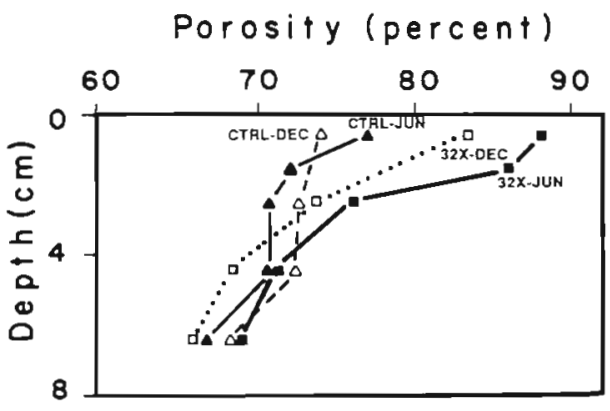

Fig. 3. Sediment porosity in control (CTRL) and $32 \times$ mesocosms, December 1982 and June 1983

was almost $2 \frac{1 / 2}{2}$ times more solid in the surface control sediments (porosity $75.8 \%$ ) than in the $32 \times$ sediments (porosity $91.8 \%$ ). No differences were noted below $6 \mathrm{~cm}$ in depth for any treatment.

\section{Redox discontinuity layer}

The redox discontinuity layer ( $R D L$, zone of rapid change from positive to negative Eh values) was normally between 3 and $6 \mathrm{~cm}$ in control sediments. Eh was sensitive to changes brought on by eutrophication, with the RDL commonly within the top $2 \mathrm{~cm}$ for all treatment tanks (Fig. 4). Negative Eh was recorded in the surface $1 \mathrm{~cm}$ in the summer in some of the mesocosms. Such a shift in Eh may have important implications for metal and phosphorus cycling. Summer inorganic phosphorus benthic fluxes were an order of magnitude higher in the treatments than in control (Frithsen et al. 1985). The annual cycle for all the mesocosms showed a summer shallowing of the RDL from the more oxidized winter and early spring conditions.

No major differences in porewater $\mathrm{pH}$ were seen among control, $4 \times$, and $8 \times$. Subsurface $\mathrm{pH}$ minimum ( $\mathrm{pH} 6.9$ to 7.2 ) were measured in $16 \times$ and $32 \times$ sediments, possibly indicating active zones of sulfide oxidation (Goldhaber \& Kaplan 1974, Howarth \& Jorgensen 1984). Porewater sulfate concentrations showed some surface depletion in the highest-loaded treatments but remained above $15 \mathrm{mM}$ throughout the experiment in all tanks, at all depths.

\section{Sulfate reduction rates}

Changes in the magnitude and spatial location of maximum sulfate reduction rates occurred throughout the treatment gradient (Fig. 5). In control sediments sulfate reduction exhibited a strong seasonal cycle. The annual range between winter minima and summer maxima embraced an order of magnitude 20 to 300 nmol $\mathrm{SO}_{4}$ reduced $\mathrm{cm}^{-3} \mathrm{~d}^{-1}$ ). Subsurface peaks in reduction rates were also characteristic of the control Although the absolute rates in $4 \times$ did not differ from control, the zone of maximum anaerobic metabolism shifted from subsurface to near surface. Sulfate reduction rates became increasingly higher and were most pronounced in the surface sediments of higher treatments. Throughout the year maximum rates in the $8 \times$, $16 \times$ and $32 \times$ sediments were in the surface 0 to $2 \mathrm{~cm}$ of sediment. These elevated surface rates were an order of magnitude higher than control rates. Sulfate reduction rates greater than $1000 \mathrm{nmol} \mathrm{cm}{ }^{-3} \mathrm{~d}^{-1}$ were common in the $16 \times$ and $32 \times$ sediments. The highest rates $\left(>2800 \mathrm{nmol} \mathrm{SO}_{4}\right.$ reduced $\mathrm{cm}^{-3} \mathrm{~d}^{-1}$ ) occurred in July 1983 in the $32 \times$ treatment when temperatures were at their yearly maximum $\left(20^{\circ} \mathrm{C}\right)$. Sulfate reduction rates for each treatment were higher during summer 1983 than during summer 1982. Interannual and intertreatment differences in sulfate reduction metabolism were not observed at depths $>7 \mathrm{~cm}$.

\section{Integrated anaerobic metabolism}

Integrated anaerobic metabolism reflected the seasonal changes apparent in the downcore profiles and the effects of treatment (Fig. 5). Control sediments displayed a 10-fold seasonal range, from a late February minimum of $5 \mathrm{mmol} \mathrm{C} \mathrm{m} \mathrm{Cd}^{-1}$ to a summertime maximum of 40 to $60 \mathrm{mmol} \mathrm{m} \mathrm{m}^{-2} \mathrm{~d}^{-1}$. The effect of nutrient loading was to increase the annual range of integrated sulfate reduction. Maximum summer rates in 1983 increased along the treatment gradient with 68, 96, 153 and $237 \mathrm{mmol} C$ remineralized $\mathrm{m}^{-2} \mathrm{~d}^{-1}$ for $4 \times$, $8 \times, 16 \times$ and $32 \times$ respectively.

\section{Sediment oxygen consumption}

All treatments exhibited a strong seasonal pattern of SOC (Fig. 5). Winter oxygen uptake rates were low for all tanks and ranged from 7 to $22 \mathrm{mmol} \mathrm{O}_{2} \mathrm{~m}^{-2} \mathrm{~d}^{-1}$. Maximum summer rates for the control benthos were 50 to $70 \mathrm{mmol} \mathrm{O} 2 \mathrm{~m}^{-2} \mathrm{~d}^{-1}$. SOC in the $4 \times$ treatment exceeded control rates only during summer. Summer oxygen consumption in $8 \times, 16 \times$ and $32 \times$ always exceeded control rates, with the exception of a flux on 17 August 1982 in the $32 \times$ treatment, which was the 


\section{$E h(m V)$}
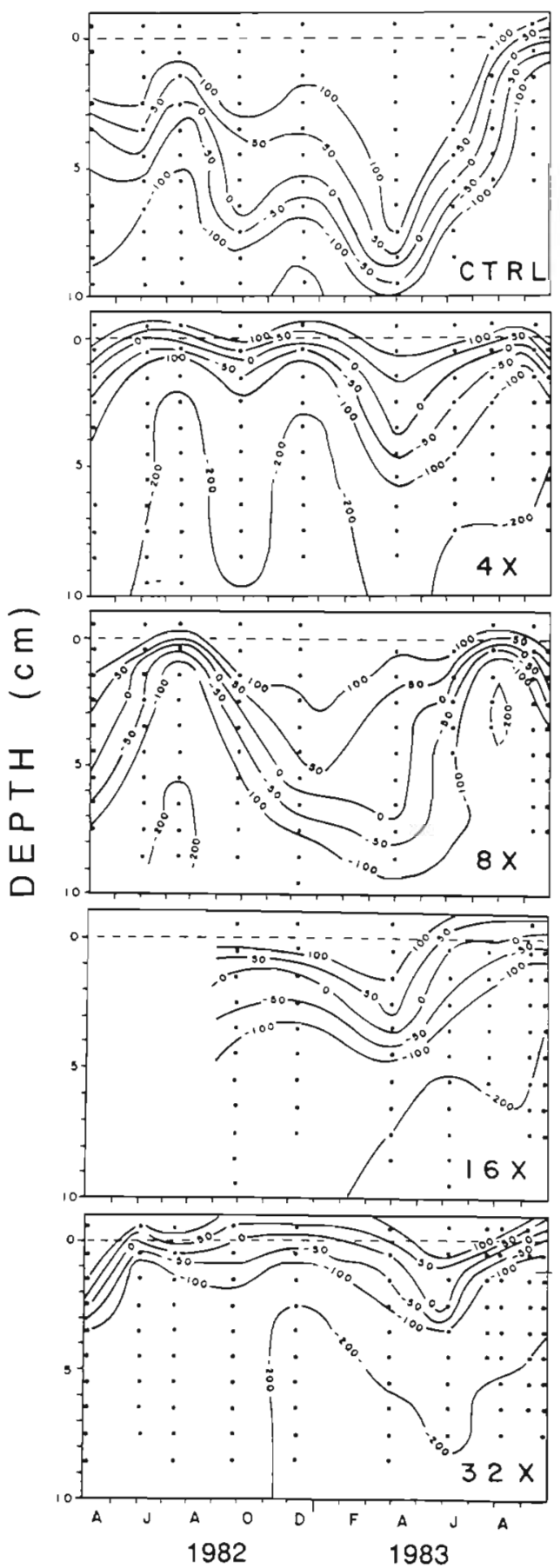

Fig. 4. Redox potentials for control (CTRL) $4 \times, 8 \times, 16 \times$ and $32 \times$ sediments (April 1982 to September 1983). Eh (mV) isopleths from measured values at respective depths (
SULFATE REDUCTION (nmol $\left.\mathrm{cm}^{-3} \mathrm{~d}^{-1}\right)$

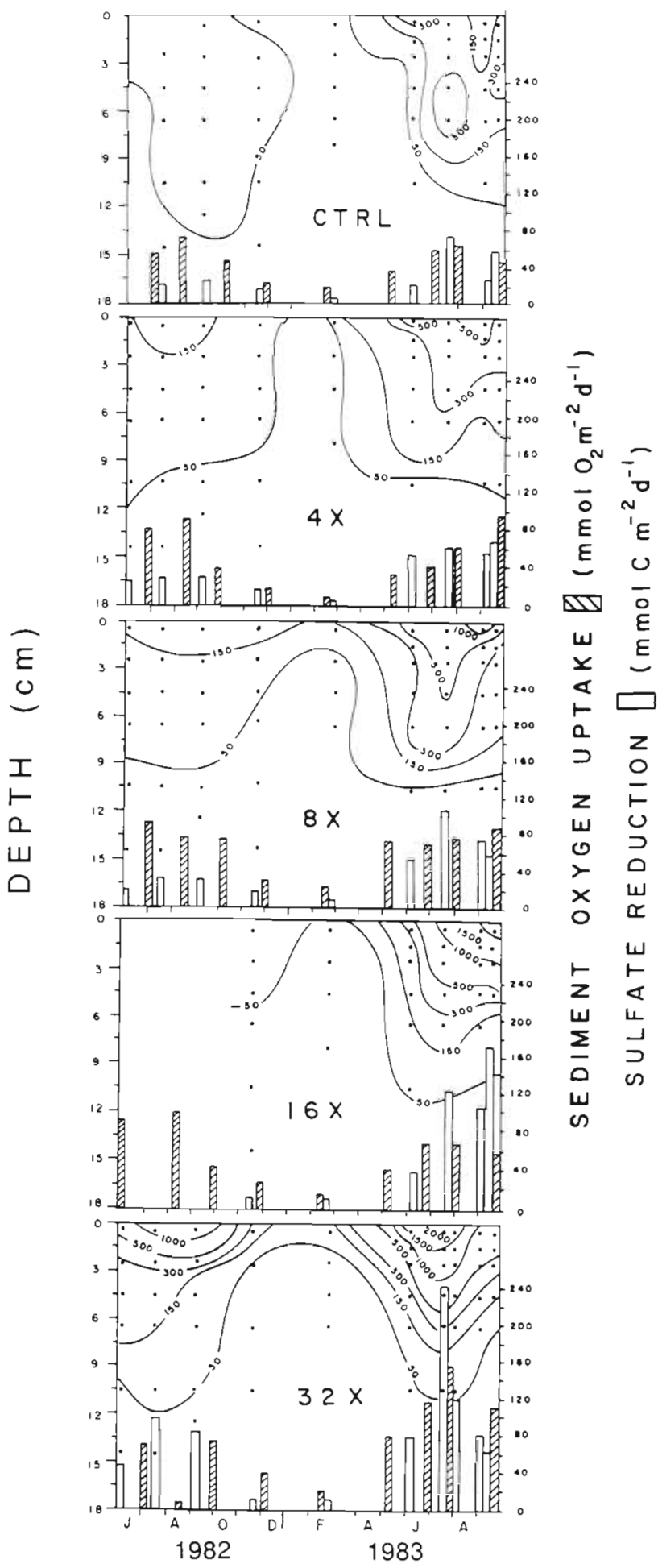

Fig. 5. Respiration rates in control (CTRL), $4 \times, 8 \times, 16 \times$ and $32 \times$ treatments (June 1982 to September 1983). Sulfate reduction ( $\mathrm{nmol}$ reduced $\mathrm{cm}^{-3} \mathrm{~d}^{-1}$ ) isopleths from measured rates at respective depths $(\bullet$ ). Integration of sulfate reduction to a depth of $15 \mathrm{~cm}$ yielded an areal metabolic rate (expressed in carbon units, mmol $\mathrm{C} \mathrm{m}^{-2} \mathrm{~d}^{-1}$ ). Sediment oxygen uptake ( $\mathrm{mmol} \mathrm{O} \mathrm{O}^{-2} \mathrm{~d}^{-1}$ ) across the sediment-water interface over the same time period also shown 
lowest of all the mesocosms and followed a period of anoxia. Maximum rates were measured in the $32 \times$ mesocosm in summer 1983 (150 $\left.\mathrm{mmol} \mathrm{O}_{2} \mathrm{~m}^{-2} \mathrm{~d}^{-1}\right)$.

\section{DISCUSSION}

\section{Seasonal accumulation of sediment carbon}

Patterns of carbon accumulation and depletion in surface sediments were similar for all treatments, with the magnitude of seasonal changes amplified up the eutrophication gradient (Fig. 2). Treatment and/or seasonal signals were additive to a large reservoir of refractory carbon in the sediments $\left(35 \mathrm{~mol} \mathrm{~m} \mathrm{~m}^{-2} 20 \mathrm{~kg}^{-1}\right)$. Both the control and $4 \times$ treatment showed a weak seasonal pattern, with slight enrichment in June (about $4 \mathrm{~mol} \mathrm{C} \mathrm{m}^{-2}$ greater than background). Maximum carbon concentrations in $8 \times$ and $16 \times$ sediments were measured in April 15 and $8 \mathrm{~mol} \mathrm{C} \mathrm{m}^{-2}$ greater than background). The $16 \times$ sediments also had a secondary build-up of carbon in September 1983. Maximum sediment carbon accumulation in the $32 \times$ treatment was measured in June, when there were $17 \mathrm{~mol} \mathrm{C} \mathrm{m}{ }^{-2}$ more than in December 1982. The cycle of winter-spring accumulation of sedimentary carbon was generally balanced by remineralization over summer and fall, with little or no net annual accumulation of organic material. Elevated carbon concentrations in treated sediments at the end of the experiment in September 1983 were more a function of seasonal cycles within each treatment than a lasting effect of eutrophication.

Sediments were the only component capable of significant storage of organic matter. Planktonic biomass was $<15 \mathrm{~g} \mathrm{C} \mathrm{m}^{-2}$ even during the highest blooms (Frithsen et al. 1985). Export of particulate and dissolved organic carbon was small in the carbon budget of an $8 \times$ treatment in a similar experiment (Sampou 1989). Although seasonal macrofaunal changes did store up to $25 \mathrm{~g} \mathrm{C} \mathrm{m}^{-2}$ in the $8 \times$ treatment, faunal biomass exhibited an annual variation of $<10 \mathrm{~g} \mathrm{C} \mathrm{m}^{-2}$ for the other treatments (Frithsen et al. 1985).

Eutrophication accentuated the seasonality of food supply to the benthos. Comparison of sediment carbon accumulation with rates of benthic respiration illustrates the importance of the winter-spring carbon deposition on both seasonal and annual time scales. The winter-spring increase in sediment carbon peaked between April and June 1983 and was 4, 4, 5, 8 and $17 \mathrm{~mol} \mathrm{C} \mathrm{m} \mathrm{m}^{-2}$ for control, $4 \times, 8 \times, 16 \times$ and $32 \times$ treatments, respectively (Table 1 ). Average sulfate reduction metabolism in early summer (June through July 1983) for control, $4 \times, 8 \times, 16 \times$ and $32 \times$ was $42,57,73$, 73 and $157 \mathrm{mmol} \mathrm{C} \mathrm{m}{ }^{-2} \mathrm{~d}^{-1}$ respectively (Fig. 5). One to three months of anaerobic metabolism could be sustained from the spring accumulation of surface carbon. Similar conclusions were reached comparing the carbon pool size with SOC. Comparison of annual SOC rates with the maximum accumulation of carbon in the surface sediments showed that seasonal deposition of carbon accounted for an increasing percentage of annual benthic respiration (Table 1). The percentage of annual respiration [using $\mathrm{SOC}$ and an annual respiratory quotient of $\left.1\left(\mathrm{RQ}=\mathrm{CO}_{2} / \mathrm{O}_{2}\right)\right]$ that could be fueled from the winter-spring accumulation of sediment carbon increased from $15-20 \%$ in the lower 3 treatments (control, $4 \times, 8 \times$ ) to over 30 and $40 \%$ in $16 \times$ and $32 \times$ treatments respectively.

\section{Eutrophication and benthic respiratory pathways}

Carbon loading to the sediments should increase benthic metabolism; however, it would be unlikely to affect all respiratory processes similarly. Due to limitations imposed by low terminal electron acceptor (TEA) concentrations and rates of TEA diffusion into the sedi-

Table 1. Spring maximum sediment carbon accumulation $\left(\mathrm{C}_{\max }\right)$, annual integrated sediment oxygen consumption (SOCann) and annual integrated sulfate reduction $\left(\mathrm{SRED}_{a n n}\right), 22$ September 1981 through 21 September 1983. Carbon accumulation calculated at maximum excess over a background of $35 \mathrm{~mol} \mathrm{C} \mathrm{m}-120 \mathrm{~kg}^{-1}$ Percentage carbon remineralized via anaerobic pathways calculated from SOC ann and SREDann, with various assumptions of annual sulfide burial (\% of SRED ann). CTRL: control; see 'Methods' for treatment descriptions

\begin{tabular}{|c|c|c|c|c|c|c|}
\hline \multirow[t]{2}{*}{$\begin{array}{l}\text { Treat- } \\
\text { ment }\end{array}$} & \multirow[t]{2}{*}{$\begin{array}{c}\mathrm{C}_{\max } \\
\left(\mathrm{mol} \mathrm{Cm} \mathrm{m}^{-2}\right)\end{array}$} & \multirow[t]{2}{*}{$\begin{array}{c}\mathrm{SOC}_{\mathrm{am}} \\
\left(\mathrm{mol} \mathrm{O}_{2} \mathrm{~m}^{-2}\right)\end{array}$} & \multirow[t]{2}{*}{$\begin{array}{l}\mathrm{SRED}_{\text {arm }} \\
\left.\text { (mol } \mathrm{SO}_{4} \mathrm{~m}^{-2}\right)\end{array}$} & \multicolumn{3}{|c|}{$\begin{array}{l}\% \text { Anaerobic respiration } \\
\text { assuming sulfide burial of: }\end{array}$} \\
\hline & & & & $5 \%$ & $10 \%$ & $25 \%$ \\
\hline CTRL & 4 & 22.4 & 7.3 & 63 & 61 & 56 \\
\hline $4 \times$ & 4 & 20.7 & 8.7 & 81 & 78 & 70 \\
\hline $8 \times$ & 5 & 35.1 & 9.9 & 55 & 53 & 49 \\
\hline $16 \times$ & 8 & 25.0 & 9.1 & 69 & 68 & 62 \\
\hline $32 \times$ & 17 & 44.5 & 12.0 & 52 & 51 & 47 \\
\hline
\end{tabular}


ments from the water, aerobic respiration and denitrification should not increase as a constant fraction of total metabolism. Because the concentration of sulfate is orders of magnitude greater than that of more energetically favored TEAs, sulfate reduction is the dominant anaerobic pathway in marine sediments and would be expected to be preferentially stimulated by increased carbon loading to the sediments. A major fraction of $\mathrm{SOC}$ is for sulfide oxidation in coastal sediments. If sulfate reduction metabolism increases disproportionately with carbon loading, then the fraction of oxygen being used as a TEA for carbon respiration should decrease with eutrophication (Jørgensen 1977, Howarth 1984, Sampou 1989).

Summer depth-specific sulfate reduction rates in treated surface sediments increased by an order of magnitude over controls, and the integrated sulfate reduction rates in $16 \times$ and $32 \times$ were on average 2.6 and 3.3 times higher than control, respectively. At the same time, SOC in these 2 treatments was only 1.7 and 2.4 times higher than control, respectively (summer 1983). Eutrophication preferentially increased anaerobic respiration over SOC. Further comparison of summer SOC and downcore-integrated surface reduction rates revealed an inconsistency which cautions against the use of SOC as an estimate of carbon metabolism over short time scales. In all the mesocosms, carbon remineralization via anaerobic metabolism exceeded sediment oxygen uptake during the summer months and suggested

Table 2. Molar ratio of carbon remineralization via sulfate reduction to sediment oxygen consumption $\left[\mathrm{C}_{\text {SRED }}: \mathrm{SOC}\right.$, calculated as ( $\mathrm{mmol} \mathrm{C}$ remineralized $\left.\mathrm{m}^{-2} \mathrm{~h}^{-1}\right) /\left(\mathrm{mmol} \mathrm{O}_{2}\right.$ consumed $\left.\mathrm{m}^{-2} \mathrm{~h}^{-1}\right)$ ]. Measurements were made within 2 wh of each other at the dates noted. Values $>1$ suggest sulfide storage. CTRL: control treatment; see 'Methods' for treatment descriptions

\begin{tabular}{|lccccc|}
\hline Date & \multicolumn{5}{c|}{ C SRED :SOC } \\
& CTRL & $4 \times$ & $8 \times$ & $16 \times$ & $32 \times$ \\
\hline Jul 1982 & 0.34 & 0.35 & 0.35 & & 1.40 \\
Dec 1982 & 0.84 & 0.79 & 0.55 & 0.47 & 0.18 \\
Feb 1983 & 0.35 & 0.71 & 0.27 & 0.33 & 0.22 \\
Jul 1983 & 1.86 & 0.99 & 1.36 & 1.57 & 1.54 \\
Sep 1983 & 1.25 & 0.72 & 0.51 & 2.57 & 0.57 \\
\hline
\end{tabular}

storage of sulfides formed during sulfate reduction in surface sediments (Table 2) (Andersen \& Hargrave 1984, Howarth 1984, Sampou 1989). The highest ratios of sulfate reduction to sediment oxygen consumption (C $C_{\text {SRED }}$ :SOC) were observed in summer in $16 \times$ and $32 \times$. In contrast, $C_{S R E D}: S O C$ ratios were generally at their annual minimum for each treatment in February. The lowest ratios were observed in the $32 \times$ treatment in November and February. It was possible that very low
$\mathrm{C}_{\text {SRED }}$ :SOC values were a result of a large fraction of oxygen consumption being used for sulfide oxidation. This interpretation was supported by strong subsurface $\mathrm{pH}$ minima in winter $1982-83$ for both $16 \times$ and $32 \times$. Extremes in $\mathrm{C}_{\text {SRED }}$ :SOC were observed in the highesttreated tanks and suggested an increase in seasonal sediment sulfide storage up the eutrophication gradient.

Although eutrophication did increase the relative importance of anaerobic respiration in summer, annual estimates of the percentage of carbon flow through sulfate reduction did not show a clear trend. Annual SOC integrates anaerobic metabolism and is a good estimate of total benthic metabolism when burial of sulfide produced during sulfate reduction is known (Jørgensen 1977, Jørgensen et al. 1990). Sulfide burial can be as high as $75 \%$ of annual production in carbonrich coastal embayments subject to high sedimentation rates and minimal bioturbation (Berner \& Westrich 1985. Chanton et al. 1987). The mesocosms have low inorganic sedimentation rates and an active infaunal population; therefore, annual sediment sulfide storage during this experiment was assumed to be between 5 and $25 \%$ of the annual sulfate reduction rate (Jørgensen et al. 1990). Total annual sediment metabolism (September 1982 to September 1983) was calculated from SOC and the assumed percentage sulfide storage (\% Storage) using the equations

$$
\begin{aligned}
& \mathrm{TSR}=\left(2 \times \mathrm{SRED}_{\mathrm{ann}}\right)+\mathrm{SOC}_{\mathrm{aer}} \\
& \mathrm{SOC}_{\mathrm{aer}}=\mathrm{SOC}_{\mathrm{ann}}-\left[2 \times\left(\mathrm{SRED}_{\mathrm{ann}}-\mathrm{S}_{\mathrm{ppt}}\right)\right]
\end{aligned}
$$

where $\mathrm{TSR}=$ total sediment respiration; $\mathrm{SRED}_{\mathrm{ann}}=$ annual sulfate reduction; $\mathrm{SOC}_{\mathrm{aer}}=$ oxygen consumption not due to sulfide oxidation (equivalent to carbon remineralization using an $\mathrm{RQ}$ of 1): $\mathrm{SOC}_{\mathrm{ann}}=$ annual sediment oxygen uptake; and $\mathrm{S}_{\mathrm{ppt}}=$ number of moles of sediment sulfide stored over an annual cycle (\% Storage $\times$ SRED $_{a n n}$ ). Carbon metabolism via nitrate reduction would be incorporated into $\mathrm{SOC}_{\text {aer }}$ since allochthonous nitrate inputs were insignificant. Methanogenesis was also an insignificant metabolic pathway, given the high concentrations of sulfate that were maintained in the sediments $\left(\left[\mathrm{SO}_{4}\right]>10 \mathrm{mM}\right)$.

Percentage of carbon remineralized through anaerobic respiration was determined by the ratio of sulfate reduction to total sediment respiration. Sulfate reduction was the dominant pathway for benthic carbon remineralization in all treatments, regardless of the percentage of sulfide burial (Table 1). The $4 \times$ and $16 \times$ treatments displayed the highest percentage of anaerobic respiration ( 60 to $80 \%$ ), while in $8 \times$ and $32 \times$ only about $50 \%$ of total metabolism occurred through sulfate reduction. Contrary to summer observations, there was no relationship between nutrient/carbon loading and the proportion of carbon metabolized through sulfate reduction over an annual cycle. 
Other factors may have interacted to change the supply of oxygen to the sediments and so influence the proportion of anaerobic metabolism when averaged over an annual cycle. High concentrations of sediment carbon were seasonal and declined to background concentrations in all the mesocosms during the late fall and early winter. Minimum carbon concentrations coincided with cold temperatures and low sulfate reduction rates. These conditions would favor increased oxygen penetration and sediment sulfide oxidation in the surface sediments. High summer SRED rates could be balanced by high SOC rates (due to inorganic oxidations) during fall and winter. The net result of such an annual cycle would be little or no annual accumulation of either sediment carbon or sulfides.

Macrofaunal irrigation can have a major influence on respiratory pathways by increasing oxygen flux across the sediment-water interface (Aller 1982, Fisher 1982). Some obvious differences in macrofaunal populations existed among treatments and could have affected the percentage of sediment metabolism via anaerobic respiration. The $32 \times$ and $8 \times$ benthos were characterized by very high populations of macrofauna, with 100000 and 200000 ind. $\mathrm{m}^{-2}$, respectively, over the last year of the experiment. In contrast, the 2 mesocosms with a higher percentage of anaerobic respiration (Treatments $4 \times$ and $16 \times$ ) had fewer macrofauna, averaging only 10000 to 100000 ind $\mathrm{m}^{-2}$ (Frithsen et al. 1985). Trends seen in macrofaunal populations were consistent with the calculated ratios of percentage carbon flow through anaerobic respiration. The very low redox potential of the $4 \times$ sediments also supported the conclusion of a high percentage carbon flow through sulfate reduction. The irrigational effects of high populations of macrofauna may influence carbon respiratory pathways more strongly than does carbon-loading to sediments in temperate marine systems.

\section{Sulfate reduction as a function of temperature and organic matter}

Sulfate reduction rates responded to seasonal patterns of temperature and sediment carbon concentrations. A multiple regression analysis (SAS, Carey, N Carolina, USA) was performed for individual sulfate reduction rates as a function of temperature $\left(T^{\circ} \mathrm{C}\right)$ and percentage carbon ( $\% \mathrm{C})$. Natural log transformation of sulfate reduction rates [ln (SRED)] resulted in a residual error which was independent of reduction rates. The data used for regression analyses was divided into 2 groups. One set of data was restricted to sediments with carbon concentrations $>2.5 \%$ and included the surface sediments of $8 \times, 16 \times$, and $32 \times$. Another set of data contained only low carbon concentrations $(\% \mathrm{C}$
$<2.3)$. Analysis of the data as 2 subsets was based on the fact that a large percentage of sediment organic carbon is refractory and not correlated to concentrations of microbial substrate (Howarth \& Hobbie 1982). However, percentage carbon could be correlated to substrate availability in enriched sediments. Inclusion of data with corresponding carbon concentrations between 2.3 and $2.5 \%$ in either of the 2 data sets resulted in larger errors associated with the regression coefficients. Multiple regressions were run on these 2 data sets. For carbon concentrations $<2.3 \%$ : $\ln (\operatorname{SRED})=\left(0.193 \times T^{\circ} \mathrm{C}\right)+1.51\left(\mathrm{r}^{2}=0.71, \mathrm{n}=102\right) ;$ for carbon concentrations $>2.5 \%: \ln ($ SRED $)=(0.474$ $\times \% \mathrm{C})+\left(0.141 \times T^{\circ} \mathrm{C}\right)+2.26\left(\mathrm{r}^{2}=0.85, \mathrm{n}=18\right)$.

The relationship between sulfate reduction, temperature and percentage carbon was strong in enriched sediments $\left(r^{2}=0.85\right)$. In the eutrophic treatments, the mass of seasonally deposited organic matter was sufficiently large (compared to the pool of less reactive sediment organic matter) to be an indicator of substrate available for bacteria. Percentage carbon was not a significant factor. in explaining annual variability of sulfate reduction rates in control sediments.

Acknowledgements. This work was supported by EPA Cooperative Agreements 87795-01, 87795-02, and 810265-01 Special thanks to the Andrew Mellon Foundation for additional funding to pursue this specific research. Invaluable help and assistance were provided by Robert Howarth. We wish to acknowledge the indispensable help of the students and staff of the MERL facility who made this research possible: E. Klos, S. Kelly, A. Keller, D. Rudnick, J. Frithsen, L. Beatty, V Berounsky and R. Chinman.

\section{LITERATURE CITED}

Alldredge, A. L., Gotschalk, C. C. (1989). Direct observations of the mass flocculation of diatom blooms: characteristics, settling velocities and formation of diatom aggregates. Deep Sea Res. 36: 159-171

Aller, R. C. (1982). The effects of macrobenthos on chemical properties of marine sediment and overlying water. In: McCall, P. L., Tevesz, M. J. (eds.) Animal-sediment relations: the biogenic alteration of sediments. Plenum Press, New York, p. 53-102

Andersen, F. O., Hargrave, B. T (1984). Effects of Spartina detritus enrichment on aerobic/anaerobic benthic metabolism in an intertidal sediment. Mar. Ecol. Prog. Ser 16: $161-171$

Berner, R. A. (1978). Sulfate reduction and the rate of deposition of marine sediments. Earth planet. Sci. Lett. 37: 492-498

Berner, R. A., Westrich, J. T (1985). Bioturbation and the early diagenesis of carbon and sulfur. Am. J. Sci. 285: 193-206

Boynton, W. R., Kemp, W. M., Keefe, C. W. (1982). A comparative analysis of nutrients and other factors influencing estuarine phytoplankton production. In: Kennedy, V S. (ed.) Estuarine comparisons. Academic Press, New York, p. $69-90$

Canfield, D. E., Raiswell, R., Westrich, J. I., Reaves, C. M., 
Berner, R. A. (1986). The use of chromium reduction in the analysis of reduced inorganic sulfur in sediment and shales. Chem. Geol. 54: 149-155

Chanton, J. P., Martens, C. S. (1987). Biogeochemical cycling in an organic-rich coastal marine basin. 7. Sulfur mass balance, oxygen uptake and sulfide retention. Geochim. cosmochim. Acta $51 \quad 1187-1199$

Fisher, J. B. (1982). Effects of macrobenthos on the chemica! diagenesis of freshwater sediments. In: McCall, P. L., Tevesz, M. J. (eds.) Animal-sediment relations: the biogenic alteration of sediments. Plenum Press, New York, p. $177-218$

Frithsen, J. B., Keller, A. A., Pilson, M. E. Q. (1985). Effects of inorganic nutrient additions in coastal areas: a mesocosm experimental data report. MERL Series, Report No. 3. University of Rhode Island, Kingston

Frithsen, J. B., Rudnick, D. T., Elmgren, R. (1983). A new, flow-through corer for the quantitative sampling of surface sediments. Hydrobiologia 99: 75-79

Goldhaber, M. B., Kaplan, I. R. (1974). The sulfur cycle. In: Goldberg, E. D. (ed.) The sea. Wiley, New York, p. 569-655

Graf, G., Bengtsson, W., Diesner, U., Schultz, R., Theede, H. (1982). Benthic response to sedimentation of a spring phytoplankton bloom: process and budget. Mar. Biol. 67 : 201-208

Graf, G., Bengtsson, W., Faubel, L., Meyer-Reil, L., Schulz, R., Theede, H., Thiel, H. (1984). The importance of the spring phytoplankton bloom for the benthic system of Kiel Bight. Rapp. P.-v. Réun. Cons. int. Expor. Mer 183: 136-143

Howarth, R. W. (1978). A rapid and precise method for determining sulfate in seawater, estuarine waters and sediment porewaters. Limnol. Oceanogr 23: 1066-1069

Howarth, R. W. (1984). The ecological significance of sulfur in the energy dynamics of salt marsh and coastal marine sediments. Biogeochemistry (Dordrecht) 1: 5-27

Howarth, R. W., Hobbie, J. (1982). The regulation of decomposition and heterotrophic microbial activity in salt marsh soils: a review. In: Kennedy, V. S. (ed.) Estuarine comparisons. Academic Press, New York, p. 103-127

Howarth, R. W., Jorgensen, B. B. (1984). Formation of 35Slabelled elemental sulfur and pyrite in coastal marine sediments (Limfjorden and Kysing Fjord, Denmark) during short-term 35S-Sulfate reduction measurements. Geochim. cosmochim. Acta 48: 1807-1818

Howarth, R. W., Marino, R. (1984). Sulfate reduction in salt marshes with some comparisons to sulfate reduction in microbial mats. In: Cohen, Y., Castenholz, R., Halvorson, H. (eds.) Microbial mats stromatolites. Alan Liss, New York, p. 245-263

Hunt, C. D., Smith, D. L. (1983). Remobilization of metals from polluted marine sediments. Can. J. Fish. Aquat. Sci. 40: $132-142$

Jensen, M. H., Lomstein, E., Sorensen, J. (1990). Benthic ammonium and nitrate flux following sedimentation of a spring phytoplankton bloom in Aarhus Bight, Denmark. Mar. Ecol. Prog. Ser 61: 87-96

Jørgensen, B. B. (1977). The sulfur cycle of a coastal marine sediment (Limfjorden, Denmark). Limnol. Oceanogr. 22: $814-832$

Jørgensen, B. B. (1978). A comparison of methods for the quantification of bacterial sulfate reduction in coastal marine sediments. I. Measurements with radiotracer techniques. Geomicrobiol. J. 1: 11-27

Jørgensen, B. B. (1982). Mineralization of organic matter in the sea bed, the role of sulfate reduction. Nature, Lond. 296: $643-645$
Jorgensen, B. B., Bang, M., Blackburn, T H. (1990). Anaerobic mineralization in marine sediments from the Baltic Sea-North Sea transition. Mar Ecol. Prog. Ser 59: $39-54$

Kelly, J. R., Berounsky, V. M., Nixon, S. W., Oviatt, C. A. (1985). Benthic-pelagic coupling and nutrient cycling across an experimental eutrophication gradient. Mar. Ecol. Prog. Ser. 26: 207-219

Kelly, J. R., Nixon, S. W. (1984). Expenmental studies of the effect of organic deposition on the metabolism of a coastal marine bottom community. Mar. Ecol. Prog. Ser. 17: $157-169$

Lambert, C. E., Oviatt, C. A. (1986). Manual of biological and geochemical techniques in coastal areas. MERL series, Report No. 1. University of Rhode Island, Kingston

Lorenzen, C. J. (1966). A method for the continuous measurement of in vivo chlorophyll concentration. Deep Sea Res. 13: 223

Malone, T C., Crocker, L. H., Pike, S. E., Wendler, B. W. (1988). Influence of river flow on the dynamics of phytoplankton production in a partially stratified estuary. Mar Ecol. Prog. Ser. 48: 235-249

Martens, C. S., Klump, J. Val. (1984). Biogeochemical cycling in an organic-rich coastal marine basin. 4. An organic carbon budget for sediments dominated by sulfate reduction and methanogenesis. Geochim cosmochim. Acta 48 $1987-2004$

Nixon, S. W (1981). Remineralization and nutrient cycling in coastal marine ecosystems. In: Neilson, B., Cronin, L. E (eds.) Estuaries and nutrients. Humana Press, Clifton, p. $111-138$

Nixon, S. W., Alonso, D., Pilson, M. E. Q., Buckley, B. A (1980). Turbulent mixing in aquatic microcosms. In: Giesy, J. A. (ed.) Microcosms in ecological research. DOE symposium series, Augusta, GA, Nov. 8-10, 1978. CONF 781101. Natl. Tech. Info Serv., Springfield, Virginia 22150 , p. $818-849$

Nixon, S. W., Pilson, M. E. Q., Oviatt, C. A., Donaghay, P. Sullivan, B., Seitzinger, S., Ruanick, D., Frithsen, J. (1984). Eutrophication of a coastal marine ecosystem - an experimental study using the MERL microcosms. In: Fasham, M. J. R. (ed.) Flows of energy and materials in marine ecosystems: theory and practice. Plenum Press, New York, p $105-135$

Oviatt, C. A., Frithsen, J. B., Gearing, J., Gearing, P. (1982) Low chronic additions of No. 2 fuel oil: chemical behavior biological impact and recovery in a simulated estuarine environment. Mar. Ecol. Prog. Ser 9: 121-136

Oviatt, C. A., Keller, A. A., Sampou, P., Beatty, L. L. (1986) Patterns of productivity during eutrophication: a mesocosm experiment Mar. Ecol. Prog. Ser. 28: 69-80

Oviatt, C. A., Pilson, M. E. Q., Nixon, S. W., Frithsen, J. B., Rudnick, D. T., Kelly, J. R., Grassle, J. R., Grassle, J. P. (1984). Recovery of a polluted estuarine system: a mesocosm experiment. Mar. Ecol. Prog. Ser. 16: 203-217

Peinert, R., Saure, A., Stegmann, P., Stienen, C., Hardt, H. Smetacek, V. (1982). Dynamics of primary production and sedimentation in a coastal ecosystem. Neth. J. Sea Res. 16 $276-289$

Pilson, M. E. Q., Oviatt, C. A., Vargo, G. A., Vargo, S. L (1979). Replicability of MERL microcosms: initial observations. In: Jacoff, F. S. (ed.) Advances in marine environmental research, proceedings of a symposium, June 1977 EPA-600/9-79-035, U.S. Environ. Protect. Agency, Narragansett, Rhode Island, p. 361-383

Pratt, D. M. (1965). The winter-spring diatom flowering in Narragansett Bay. Limnol. Oceanogr. 10: 173-184 
Riebesell, U. (1989). Comparison of sinking and sedimentation rate measurements in a diatom winter/spring bloon. Mar Ecol. Prog. Ser. 54: 109-119

Rudnick, D. (1984). Seasonality of community structure and carbon flow in Narragansett Bay sediments. Ph.D. thesis, University of Rhode Island, Kingston

Rudnick, D. T., Oviatt, C. A. (1986). Seasonal lags between organic carbon deposition and mineralization in marine sediments. J. mar. Res. 4: 815-837

Sampou, P. (1989). Effects of eutrophication on the biogeochemical cycling of carbon, oxygen, sulfur and energy in coastal marine ecosystems. Ph.D. thesis, University of Rhode Island, Kingston

Sawyer, D. T., Robert, J. L. (1974). Experimental electrochemistry for chemists. John Wiley \& Sons, New York

Smayda, T J. (1973). The growth of Skeletonema costatum during a winter-spring bloom in Narragansett Bay, Rhode Island. Norw. J. Bot. 20: 219-247

Smetacek, $V$ (1984). The supply of food to the benthos. In: Fasham, M. J. R. (ed.) Flows of energy and materials in

This article was submitted to the editor marine ecosystems: theory and practice. Plenum Press, New York, p. 105-135

Smetacek, V., Bodungen, B. von, Knoppers, B., Peinert, R. Pollehne, F., Stegmann, P., Zeitzschel, B. (1984). Seasonal stages characterizing the annual cycle of an inshore pelagic system. Rapp. P.-v. Réun. Cons. int. Explor. Mer 183: $126-135$

Sorensen, J., Jørgensen, B. B., Revsbech, N. P. (1979). A comparison of oxygen, nitrate and sulfate respiration in coastal marine sediments. Microb. Ecol. 5: 105-115

Toth, D. J., Lerman, A. (1977). Organic matter reactivity and sedimentation rates in the ocean. Am. J. Sci. 277: 465-485

Yentsch, C. S., Menzel, D. W. (1963). A method for the determination of phytoplankton chlorophyll and phaeophytin by fluorescence. Deep Sea Res. 10:221

Zhabina, N. M., Volkov, I. I. (1978). A method of determination of various sulfur compounds in sea sediments and rocks. In: Krumbein, W (ed.) Environmental biogeochemistry and geomicrobiology. Ann Arbor Science Publ., Ann Arbor, p. 735-746

Manuscript first received: October 16, 1990

Revised version accepted: March 18, 1991 